\title{
NONLINEAR ANALYSIS OF RC COLUMNS USING THE DRUCKER-PRAGER MODEL
}

\author{
Guray Arslan ${ }^{1}$, Melih Hacisalihoglu ${ }^{2}$ \\ Department of Civil Engineering, Ylldiz Technical University, 34210 Istanbul, Turkey \\ E-mails:1'aguray@yildiz.edu.tr; gurayarslan@yahoo.com (corresponding author); ${ }^{2}$ mhacisalih@gmail.com \\ Received 24 May 2011; accepted 04 Jul. 2011
}

\begin{abstract}
This paper aims to investigate the correct prediction of load carrying capacity of reinforced concrete (RC) columns. Although substantial experimental and analytical researches have been conducted to model and simulate the response of concrete, little success has been achieved for the general description of the failures of RC columns subjected to bending and axial load. In order to predict the load carrying capacity of RC column, this paper introduces a new relationship for calculating the cohesion parameter of Drucker-Prager criterion. The relationship is developed from a parametric study of a large number of nonlinear finite element analyses of RC columns to account for the parameters. Incorporating these parameters into the failure criterion of concrete, the failure cone of Drucker-Prager model is enforced to approximate and coincide with the whole compressive meridian of the criterion up to the analytically predicted point of the load carrying capacity in the failure analyses. The proposed approach is compared with other approaches using the available column test data to demonstrate how accurately it predicts the load carrying capacity. It is shown that the proposed approach fit quite well to the experimental results of 28 specimens tested by four different researchers.
\end{abstract}

Keywords: failure, axial load, Drucker-Prager criteria, concrete cohesion, reinforced concrete, column.

\section{Introduction}

In the last four decades, several analytical approaches and finite element models has been developed to simulate the behavior of reinforced concrete (RC) columns by using various material models for concrete. Constitutive models for concrete should be concerned with pressure sensitivity, path dependence, stiffness degradation and cyclic response. It is generally assumed that concrete behaves like an elastic-perfectly plastic material after reaching its maximum capacity, and that the failure surface is fixed in the stress space. Many yield functions have been proposed for concrete (Chen 1982). Among those, the Drucker-Prager (D-P) criterion has been widely adopted for the concrete modeling (Karabinis, Kiousis 1994, 1996; Lan 1998; Karabinis, Rousakis 2002; Mirmiran et al. 2000; Shahawy et al. 2000; Mahfouz et al. 2001; Oh 2002; Rousakis et al. 2007; Arslan 2007) because of its simplicity (two-parameter model defined by cohesion, $c$ and angle of internal friction, $\phi$ ). Pankaj and Lin (2005) studied the influence of two similar continuum plasticity models, the D-P model and the Concrete Damaged Plasticity model, on the analytical seismic response of a RC frame structure. Deniaud and Neale (2006) observed a good agreement between the elasto-plastic analysis of FRP-steel confined concrete columns with the D-P yield criterion and experimental data. Eid et al. (2007) and Eid and Paultre (2007) proposed stress-strain curves describing the axial and lateral behavior of externally confined circular concrete columns, where the curves were derived from elasto-plastic behavior of the confined concrete by using D-P yield criterion for concrete. Majewski et al. (2008) predicted the behaviour of $\mathrm{RC}$ columns subjected to eccentric compression with consideration of cracks, where concrete was described with an elasto-plastic model using D-P model. Yu et al. (2010a) proposed a modified D-P model for the modelling of confined concrete. Yu et al. (2010b) presents an improved plastic-damage model for concrete, based on the assessment of the modified D-P type model presented in the companion paper Yu et al. (2010a).

A considerable amount of nonlinear analysis has been done using (1) the von Misses criterion; (2) the Coulomb or modified Coulomb criterion; and (3) D-P criterion (Chen 1982). The D-P model incorporates isotropic hardening. The model used by Chen and Mau (1989) is too complex to adopt since it requires 24 parameters to be calibrated based on experimental results. A simple solution is usually preferred in the elasto-plastic analyses of concrete. Mirmiran et al. (2000) assumes an elasticperfectly plastic response to reduce the number of parameters by utilizing a D-P type plasticity. The parameters of the D-P were determined via a detailed calibration study based upon a sensitivity analysis.

In this paper, several aspects of the threedimensional (3D) finite element modeling of RC columns have been investigated. The emphasis was kept on the determination of the material parameters of D-P criterion in order to predict the load carrying capacity of RC columns. Employing a realistic and practical failure model of concrete which only needs cylindrical compressive strength, the cohesion and the internal friction parameters 
of D-P criterion have been adjusted through a parametric study. Providing an optimum mesh size configuration for the nonlinear finite element analysis (NLFEA), the comparison between the predictions of the present study and the experimental results of 28 columns tested by four different researchers (Atalay, Penzien 1975; Lu et al. 1999; Muguruma et al. 1989; Azizinamini et al. 1988) are to be made for the validation of the present approach (Table 1). The NLFEA of the columns, employing the D-P yield criterion for concrete, have been performed and the concrete cohesion has been investigated.

\section{Principle and modeling parameters of the Drucker- Prager (D-P) criteria}

The ductile behavior of the materials, which are weak in tension and exhibit volumetric plastic strain, can be described using the D-P yield criterion, which can be written as (Chen 1982):

$$
F\left(\sigma_{i j}\right)=\alpha I_{1}+\sqrt{J_{2}}-k,
$$

in which $I_{1}$ is the first stress invariant, $J_{2}$ is the second stress invariant, $\alpha$ and $k$ are the material constants which can be related to the friction angle $\phi$ and cohesion $c$ of the Mohr-Coulomb criterion in several ways. The material constants $\alpha$ and $k$ are (Chen 1982):

$$
\alpha=\frac{2 \sin \phi}{\sqrt{3}(3-\sin \phi)} ; k=\frac{6 c \cos \phi}{\sqrt{3}(3-\sin \phi)} .
$$

The internal friction angle is approximately between $30^{\circ}$ and $37^{\circ}$, which can be found by drawing various tangent lines to the compressive meridian, obtained from experimental data of concrete. These values have been successfully used in the previous studies (Chen 1982; Mirmiran et al. 2000; Arslan 2007; Karakoç, Köksal 1997). In Mirmiran et al. (2000) study, the cohesion, the internal friction angle, and the dilatancy angle are utilized as $8.275 \mathrm{MPa}, 28^{\circ}$, and zero degrees, respectively, for the range of concrete strengths from $29.6 \mathrm{MPa}$ to $32.0 \mathrm{MPa}$. Lubliner et al. (1989) and Oller et al. (1990) suggested that the concrete cohesion and internal friction angle for Mohr-Coulomb material constant can be taken as 2.80 $3.60 \mathrm{MPa}$ and $32^{\circ}$, respectively. Using the parametric study, Arslan (2007) recommends a relation for the cohesion, which outcomes generally between 2.1 and $6.0 \mathrm{MPa}$ for RC slender beams. In this study, internal friction angles for normal and high strength concrete are considered as $33^{\circ}$ and $37^{\circ}$, respectively.

Several concrete cohesion equations of D-P yield criterion (Chen 1982; Arslan 2007; Chen, Mau 1989; Köksal 1998; Rochette, Labossie're 1996) have been proposed to calculate the load carrying capacity of RC members. In Köksal (1998) study, an attempt has been made for determining the concrete cohesion after calibrating the results of several finite element applications and the following equation has been proposed (Köksal 1998):

$$
c=0.23 \ln \left(\frac{f_{t}^{2} d_{a}^{3}}{G_{f}}\right),
$$

in which $f_{t}$ is the tensile strength of concrete, $G_{f}$ is the fracture energy of concrete under tension and $d_{a}$ is the maximum aggregate diameter. According to Phillips and Binsheng (1993), $G_{f}$ is given as follows:

$$
G_{f}=30.5+6.64 f_{t}^{2} .
$$

Arslan (2007) proposed that the concrete cohesion parameter of D-P yield criterion is defined by means of NLFEA. The corresponding experimental results regarding the sensitivity of the D-P modeling parameters in the prediction of the nonlinear response of $\mathrm{RC}$ beams $(a / d \geq 2.5)$ to material and geometrical parameter are indicated and the following equation to calculate the concrete cohesion is given by:

$$
c=\frac{2}{3}\left(f_{c}\right)^{0.31}\left(\frac{a}{d}\right)^{0.75} e^{0.12 \rho}\left(\frac{d}{d_{a}}\right)^{-0.30},
$$

in which $\rho$ is expressed in percentage (\%) and $f_{c}$ in $\mathrm{MPa}$, $a / d$ is the shear span-to-depth ratios and $d / d_{a}$ size effect.

According to Chen (1982), the concrete cohesion is related to the angle of internal friction and the compressive strength of concrete (from control cylinders) $f_{c}$ as:

$$
c=\frac{f_{c}(1-\sin \phi)}{2 \cos \phi} .
$$

Rochette and Labossie re (1996) suggested a direct approach to calculate the angle of internal friction and the concrete cohesion as given by:

$$
\begin{aligned}
& \phi=\sin ^{-1}\left[\frac{3}{1+2 f_{c} / \sqrt{3}}\right] ; \\
& c=\left(f_{c}-5 \sqrt{3}\right) \frac{3-\sin \phi}{6 \cos \phi} .
\end{aligned}
$$

Table 2 shows the comparison between the concrete cohesion predicted by Eqs (3), (5), (6) and (8) and the concrete cohesion values of NLFEA results. It can be clearly observed that the predictions are fairly different. In order to reduce the errors which may be induced by the discrepancy of ultimate load capacity of test columns and NLFEA results, a new concrete cohesion equation of D-P yield criterion is proposed to allow a more accurate estimate of load carrying capacity of such columns.

This paper presents a careful finite element investigation into the concrete cohesion of D-P yield criterion in RC columns. The finite element software ANSYS v11.0 (2010) has been extensively used throughout the analyses. The goal of this study is to derive an analytical relation for the prediction of the concrete cohesion of RC columns based on load carrying capacity values obtained from the NLFEA. A parametric study has been performed to asses the influence of the material and geometric parameters previously identified on the load-carrying capacity. To account for the actual material behavior and to ensure the continuity of response of RC columns, attention has been paid to the definition of load carrying capacity as well as to the governing parameters $a / d, f_{c}$ and $N / N_{0}$. 


\section{Finite element modeling of RC columns}

In the numerical investigations carried out within the scope of this study, the finite element software ANSYS v11.0 (2010) was used. Data were obtained from the previously cited experiments on RC columns covering a wide range of column properties. Geometrical and material properties of the RC columns are given in Table 1 , which identifies key parameters of 28 test columns. The included columns satisfy the following criteria: column span-to-depth ratio, $2.5 \leq$ ald $\leq 5.5$; concrete strength, $27.4 \mathrm{MPa} \leq f_{c} \leq 115.8 \mathrm{MPa}$; longitudinal and transverse reinforcement nominal yield stress, $f_{y}$ and $f_{y w}$, in the range of $181 \sim 616 \mathrm{MPa}$; longitudinal reinforcement ratio, $1.67 \%$ $\leq \rho \leq 3.81 \%$; nominal stirrup strength, $0.55 \mathrm{MPa} \leq \rho_{w} f_{y w} \leq$ $12.76 \mathrm{MPa}$; cyclic lateral load reversals; and apparent flexural failure. Columns were tested by loading double ended test configurations. In this paper, the test data (Atalay, Penzien 1975; Lu et al. 1999; Muguruma et al. 1989; Azizinamini et al. 1988) are evaluated to investigate the influence of $a / d, N / N_{0}$ and $f_{c}$.

Numerous experimental studies has been carried out to investigate the effect of compressive strength of concrete $\left(f_{c}\right)$, span-to-depth ratio $(a / d)$, axial load ratio $\left(N / N_{0}\right)$, nominal stirrups strength $\left(\rho_{w} f_{y w}\right)$, longitudinal reinforcement ratio $(\rho)$ and size effect on the seismic performance of the columns. Atalay and Penzien (1975) tested $10 \mathrm{RC}$ columns to investigate the effect of axial load ratio $\left(N / N_{0}\right)$ and transverse reinforcement under reversals of lateral load. The second experimental work examined in this study was conducted by Lu et al. (1999). Besides the scale effects, general rules regarding the influences of transverse reinforcement and axial load ratio on the ductility and strength of columns were investigated on the small-scale model. The third experimental work examined in this study includes high-strength RC columns tested by Muguruma et al. (1989). Axial load ratio of these columns ranges from 0.254 to 0.629 and compressive strength of concrete of these columns are $85.7 \mathrm{MPa}$ and $115.8 \mathrm{MPa}$. The other test series verified in this study are the experimental work of Azizinamini et al. (1988), in which axial load ratios of these columns are 0.21 and 0.31 , and nominal stirrups strengths are $9.99 \mathrm{MPa}$ and $8.01 \mathrm{MPa}$. Atalay and Penzien (1975), Lu et al. (1999), Muguruma et al. (1989) and Azizinamini et al. (1988) stated in their works that the shear strength was much greater than the flexural strength of columns so that the columns were enforced to fail in pure flexure. The experimental results of these specific columns have been used to validate the concrete cohesion of D-P yield criterion.

Table 1. Geometrical and material properties of RC columns

\begin{tabular}{|c|c|c|c|c|c|c|}
\hline Column & $f_{c}(\mathrm{MPa})$ & $a / d$ & $\rho(\%)$ & $N / N_{0}$ & $\rho_{w} f_{y w}(\mathrm{MPa})$ & Section size $(\mathrm{mm} \times \mathrm{mm})$ \\
\hline $1 S 1^{\mathrm{a}}$ & 29.1 & 5.50 & 1.67 & 0.099 & 5.35 & $305 \times 305$ \\
\hline $2 \mathrm{~S}^{\mathrm{a}}$ & 30.7 & 5.50 & 1.67 & 0.094 & 3.20 & $305 \times 305$ \\
\hline $3 \mathrm{~S}^{\mathrm{a}}$ & 29.2 & 5.50 & 1.67 & 0.098 & 5.35 & $305 \times 305$ \\
\hline $4 \mathrm{~S}^{\mathrm{a}}$ & 27.6 & 5.50 & 1.67 & 0.104 & 3.20 & $305 \times 305$ \\
\hline $5 \mathrm{~S}^{\mathrm{a}}$ & 29.4 & 5.50 & 1.67 & 0.196 & 5.78 & $305 \times 305$ \\
\hline $6 \mathrm{~S} 1^{\mathrm{a}}$ & 31.8 & 5.50 & 1.67 & 0.181 & 3.46 & $305 \times 305$ \\
\hline $9^{\mathrm{a}}$ & 33.3 & 5.50 & 1.67 & 0.259 & 5.78 & $305 \times 305$ \\
\hline $10^{\mathrm{a}}$ & 32.4 & 5.50 & 1.67 & 0.266 & 3.46 & $305 \times 305$ \\
\hline $11^{\mathrm{a}}$ & 31.0 & 5.50 & 1.67 & 0.278 & 5.50 & $305 \times 305$ \\
\hline $12^{\mathrm{a}}$ & 31.8 & 5.50 & 1.67 & 0.271 & 3.29 & $305 \times 305$ \\
\hline $\mathrm{C} 2 \mathrm{H} 1^{\mathrm{b}}$ & 29.3 & 5.44 & 1.79 & 0.070 & 2.31 & $300 \times 300$ \\
\hline $\mathrm{C} 3 \mathrm{H} 2^{\mathrm{b}}$ & 33.4 & 5.35 & 2.26 & 0.200 & 0.97 & $200 \times 200$ \\
\hline $\mathrm{C} 2 \mathrm{~L}^{\mathrm{b}}$ & 33.4 & 5.44 & 1.79 & 0.070 & 2.31 & $300 \times 300$ \\
\hline $\mathrm{C} 3 \mathrm{~L} 2^{\mathrm{b}}$ & 29.3 & 5.35 & 2.26 & 0.200 & 0.97 & $200 \times 200$ \\
\hline $\mathrm{C} 5 \mathrm{H} 1^{\mathrm{b}}$ & 27.4 & 5.23 & 1.87 & 0.070 & 0.55 & $110 \times 110$ \\
\hline $\mathrm{C}^{2} \mathrm{L1}^{\mathrm{b}}$ & 27.4 & 5.23 & 1.87 & 0.070 & 0.55 & $110 \times 110$ \\
\hline $\mathrm{C} 5 \mathrm{H} 2^{\mathrm{b}}$ & 27.4 & 5.23 & 1.87 & 0.200 & 0.55 & $110 \times 110$ \\
\hline $\mathrm{C} 5 \mathrm{~L} 2^{\mathrm{b}}$ & 27.4 & 5.23 & 1.87 & 0.200 & 0.55 & $110 \times 110$ \\
\hline $\mathrm{AL}-1^{\mathrm{c}}$ & 85.7 & 2.50 & 3.81 & 0.400 & 5.29 & $200 \times 200$ \\
\hline $\mathrm{AH}-1^{\mathrm{c}}$ & 85.7 & 2.50 & 3.81 & 0.400 & 12.76 & $200 \times 200$ \\
\hline $\mathrm{AL}-2^{\mathrm{c}}$ & 85.7 & 2.50 & 3.81 & 0.629 & 5.29 & $200 \times 200$ \\
\hline $\mathrm{AH}-2^{\mathrm{c}}$ & 85.7 & 2.50 & 3.81 & 0.629 & 12.76 & $200 \times 200$ \\
\hline $\mathrm{BL}-1^{\mathrm{c}}$ & 115.8 & 2.50 & 3.81 & 0.254 & 5.29 & $200 \times 200$ \\
\hline $\mathrm{BH}-1^{\mathrm{c}}$ & 115.8 & 2.50 & 3.81 & 0.254 & 12.76 & $200 \times 200$ \\
\hline$B L-2^{c}$ & 115.8 & 2.50 & 3.81 & 0.423 & 5.29 & $200 \times 200$ \\
\hline $\mathrm{BH}-2^{\mathrm{c}}$ & 115.8 & 2.50 & 3.81 & 0.423 & 12.76 & $200 \times 200$ \\
\hline $\mathrm{NC}-2^{\mathrm{d}}$ & 39.3 & 3.00 & 1.94 & 0.206 & 9.99 & $457 \times 457$ \\
\hline $\mathrm{NC}-4^{\mathrm{d}}$ & 39.8 & 3.00 & 1.94 & 0.310 & 8.01 & $457 \times 457$ \\
\hline
\end{tabular}

Note: $N_{0}=0.85 f_{c}\left(A_{g}-A_{s t}\right)+A_{s t} f_{y h}$

${ }^{\mathrm{a}}$ Atalay and Penzien (1975); ${ }^{\mathrm{b}} \mathrm{Lu}$ et al. (1999); ${ }^{\mathrm{c}}$ Muguruma et al. (1989); ${ }^{\mathrm{d} A z i z i n a m i n i}$ et al. (1988) 
In NLFEA, a finer mesh leads to a weaker element with a premature failure, and the analysis does not reflect the actual load carrying capacity and deformational pattern (Arslan 2007; Köksal, Arslan 2004). In order to obtain realistic results from the numerical simulation of RC members avoiding the mesh dependency problem, optimum mesh size is used. In this study, optimum mesh size, which is about 4 times the maximum aggregate size, is adopted for the NLFEA of RC columns.

Reinforcements have been modelled discretely using Link8 element. Solid45 elements have been used at the supports and at the loading regions to prevent stress concentrations. The concrete has been modelled using Solid65 eight-node brick element, which is capable of simulating the cracking and crushing behavior of brittle materials. The Solid65 element requires linear isotropic and multiaxial isotropic material properties to properly model the concrete. The NLFEA of the columns have been performed by employing the D-P yield criterion for concrete. A full bond is assumed between the reinforcement and the concrete components implying compatible deformation. A load-controlled analysis has been performed by increasing the load at the tip of the column incrementally. Only the half of the column has been modelled due to the symmetry of the loading and geometry. The analysis has been carried out using Newton-Raphson technique.
The tensile strength $f_{t}$ of concrete is taken as $0.3 f_{c}^{2 / 3}$ (EC 2004; CST 1998). The direct tensile strength of concrete is assumed as $f_{t}=0.3 f_{c}^{2 / 3}$ and the modulus of elasticity $E_{c}$ is taken as $4700 \sqrt{f_{c}}$ (ACI $318 \mathrm{M}-08$ 2008) for normal strength concrete and $E_{c}=3320 \sqrt{f_{c}}+6900(\mathrm{MPa})$ for high strength concrete (ACI 363R-92 1997).

\section{Development of new concrete cohesion prediction equations}

From the NLFEA results (Table 2) it appears that the development of a new equation for the concrete cohesion of D-P yield criterion requires the use of the three significant variables: $a / d, f_{c}$ and $N / N_{0}$. The first step in this analysis is to determine the basic format of the concrete cohesion equation using parametric study. The resulting function is as follows:

$$
c=k \cdot f\left(\frac{a}{d}, \frac{N}{N_{0}}, f_{c}\right),
$$

in which $k$ is the constant (see Table 2).

Table 2. The concrete cohesion values of D-P yield criterion

\begin{tabular}{|c|c|c|c|c|c|c|}
\hline Column & $\begin{array}{c}c(\mathrm{MPa}) \\
(\mathrm{NLFEA})\end{array}$ & $\begin{array}{l}c(\mathrm{MPa}) \\
\text { (Eq. (3)) }\end{array}$ & $\begin{array}{l}c(\mathrm{MPa}) \\
(\mathrm{Eq} .(5))\end{array}$ & $\begin{array}{l}c(\mathrm{MPa}) \\
(\mathrm{Eq} .(6))\end{array}$ & $\begin{array}{l}c(\mathrm{MPa}) \\
(\mathrm{Eq} .(8))\end{array}$ & $\begin{array}{c}c(\mathrm{MPa}) \\
\text { (Prop. Eq. (14)) }\end{array}$ \\
\hline $1 \mathrm{~S}^{\mathrm{a}}$ & 19.50 & 1.53 & 3.88 & 13.34 & 9.96 & 16.56 \\
\hline $2 \mathrm{~S}^{\mathrm{a}}$ & 16.50 & 1.53 & 3.95 & 14.14 & 10.75 & 16.85 \\
\hline $3 \mathrm{~S}^{\mathrm{a}}$ & 19.00 & 1.53 & 3.89 & 13.39 & 10.01 & 16.56 \\
\hline $4 \mathrm{~S}^{\mathrm{a}}$ & 16.50 & 1.52 & 3.82 & 12.59 & 9.22 & 16.27 \\
\hline $5 \mathrm{~S}^{\mathrm{a}}$ & 22.50 & 1.53 & 3.90 & 13.49 & 10.11 & 18.56 \\
\hline $6 \mathrm{~S}^{\mathrm{a}}$ & 19.00 & 1.54 & 3.99 & 14.68 & 11.30 & 19.03 \\
\hline $9^{\mathrm{a}}$ & 24.00 & 1.54 & 4.05 & 15.43 & 12.04 & 20.60 \\
\hline $10^{\mathrm{a}}$ & 20.50 & 1.54 & 4.02 & 14.98 & 11.60 & 20.42 \\
\hline $11^{\mathrm{a}}$ & 24.00 & 1.53 & 3.96 & 14.28 & 10.90 & 20.14 \\
\hline $12^{\mathrm{a}}$ & 20.50 & 1.54 & 3.99 & 14.68 & 11.30 & 20.30 \\
\hline $\mathrm{C} 2 \mathrm{H} 1^{b}$ & 14.00 & 1.68 & 4.13 & 13.44 & 10.06 & 15.47 \\
\hline $\mathrm{C} 3 \mathrm{H} 2^{b}$ & 16.50 & 1.70 & 5.08 & 15.48 & 12.09 & 19.08 \\
\hline $\mathrm{C}^{2} \mathrm{L1}^{\mathrm{b}}$ & 14.00 & 1.70 & 4.31 & 15.48 & 12.09 & 16.48 \\
\hline $\mathrm{C} 3 \mathrm{~L}^{\mathrm{b}}$ & 16.50 & 1.68 & 4.87 & 13.44 & 10.06 & 17.92 \\
\hline $\mathrm{C} 5 \mathrm{H} 1^{b}$ & 15.00 & 0.56 & 3.30 & 12.49 & 9.12 & 14.21 \\
\hline $\mathrm{C} \mathrm{LI}^{\mathrm{b}}$ & 14.50 & 0.56 & 3.30 & 12.49 & 9.12 & 14.21 \\
\hline $\mathrm{C} 5 \mathrm{H} 2^{\mathrm{b}}$ & 18.00 & 0.56 & 3.30 & 12.49 & 9.12 & 16.81 \\
\hline${\mathrm{C} 5 \mathrm{~L} 2^{\mathrm{b}}}$ & 18.00 & 0.56 & 3.30 & 12.49 & 9.12 & 16.81 \\
\hline $\mathrm{AL}-1^{\mathrm{c}}$ & 11.50 & 1.12 & 3.51 & 41.58 & 38.15 & 11.81 \\
\hline $\mathrm{AH}-1^{\mathrm{c}}$ & 11.50 & 1.12 & 3.51 & 41.58 & 38.15 & 11.81 \\
\hline$A L-2^{c}$ & 13.00 & 1.12 & 3.51 & 41.58 & 38.15 & 12.69 \\
\hline $\mathrm{AH}-2^{\mathrm{c}}$ & 13.00 & 1.12 & 3.51 & 41.58 & 38.15 & 12.69 \\
\hline $\mathrm{BL}-1^{\mathrm{c}}$ & 12.00 & 1.13 & 3.85 & 56.63 & 53.19 & 12.68 \\
\hline $\mathrm{BH}-1^{\mathrm{c}}$ & 12.00 & 1.13 & 3.85 & 56.63 & 53.19 & 12.68 \\
\hline$B L-2^{c}$ & 16.50 & 1.13 & 3.85 & 56.63 & 53.19 & 13.76 \\
\hline $\mathrm{BH}-2^{\mathrm{c}}$ & 16.50 & 1.13 & 3.85 & 56.63 & 53.19 & 13.76 \\
\hline $\mathrm{NC}-2^{\mathrm{d}}$ & 9.50 & 1.71 & 2.62 & 18.42 & 15.02 & 9.37 \\
\hline $\mathrm{NC}-4^{\mathrm{d}}$ & 7.00 & 1.71 & 2.63 & 18.67 & 15.27 & 10.07 \\
\hline
\end{tabular}




\subsection{Parametric study}

A parametric study has been undertaken to identify the influence of various parameters on the concrete cohesion of RC columns using finite element investigation and to define factor $\mathrm{k}$ and function in Eq. (9) more precisely. The variables considered are: span-to-depth ratio ald (ranging from 2.50 to 5.50), axial load ratio $N / N_{0}$ (ranging from 0.07 to 0.63 ), compressive strength of concrete $f_{c}$ (ranging from 27.40 to $115.80 \mathrm{MPa}$ ), main longitudinal reinforcement ratio $\rho$ (ranging from $1.67 \%$ to $3.81 \%$ ), nominal strength of stirrup $\rho_{w} f_{y w}$ (ranging from 0.55 to 12.76) and size effect $d / d_{a}$ (ranging from 7.06 to 19.50). Test specimens are double ended and loaded with point loads and axial loads. Span-to-depth ratio, axial load ratio and compressive strength of concrete were found to be the significant parameters, and the function in Eq. (9) was determined as:

$$
c=k\left(\frac{a}{d}\right)^{b 1}\left(\frac{N}{N_{0}}\right)^{b 2} f_{c}^{b 3} .
$$

The value of the concrete cohesion of D-P yield criterion was computed by NLFEA and the exponents $b 1$, $b 2$, and $b 3$, and the coefficient $k$ in Eq. (10) were determined from multiple regression analysis.

\subsubsection{Influence of $\mathbf{a} / \mathbf{d}$ on concrete cohesion}

Pujol et al. (2000) used an expression, attributed to Richart et al. (1929) that is a function of the cohesion coefficient, the concrete compressive strength and the average stress normal to the potential failure plane, to predict the ultimate shear stress capacity. The cohesion coefficient used by Pujol et al. (2002) depends on the maximum drift ratio and span-to-depth ratio $(a / d)$.

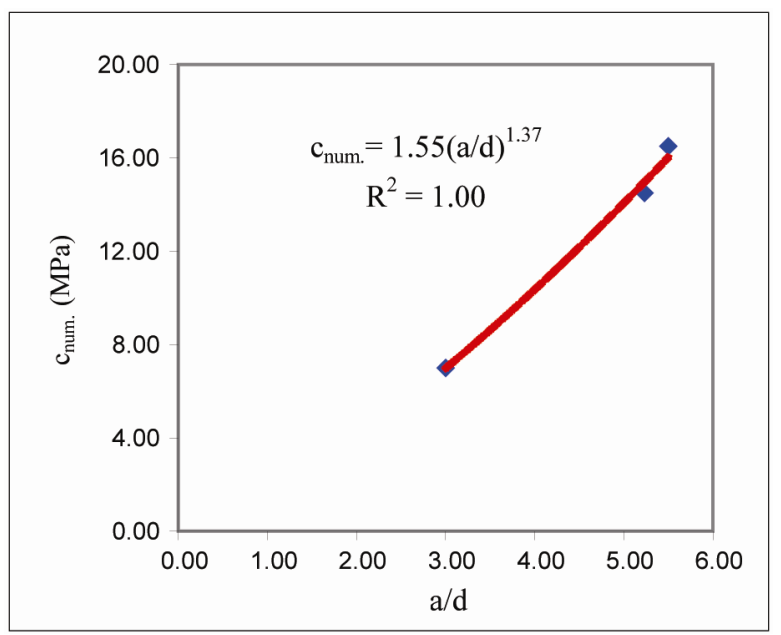

Fig. 1. Influence of $a / d$ on the concrete cohesion of D-P yield criterion

The effect of $a / d$ on the concrete cohesion is illustrated in Fig. 1. The results of NLFEA for the columns NC-4, C5L1, 4S1, where $a / d=3,5.23$ and 5.50, respectively, indicate that concrete cohesion increases sharply with $a / d$. The proposed equation matches closely with the results of NLFEA. Based on this parametric study, the concrete cohesion was found to be approximately proportional to $(a / d)^{1.37}$ for slender columns $(a / d \geq 2.5)$. The variation of concrete cohesion for slender columns can be expressed as follows:

$$
c_{n u m}=1.55\left(\frac{a}{d}\right)^{1.37}
$$

\subsubsection{Influence of $N / N_{0}$ on concrete cohesion}

The model of Pujol et al. (2000) states that the cohesion term in Coulomb's criterion depends on the drift ratio capacity and span-to-depth ratio. The drift capacity of a column reduces as the axial load level increases according to Panagiotakos and Fardis (2001), Lynn (2001), Sezen (2002), Sasani (2007), Bae and Bayrak (2009). Axial load ratio directly affects the depth of the compressive zone and therefore affects the drift capacity of RC columns.

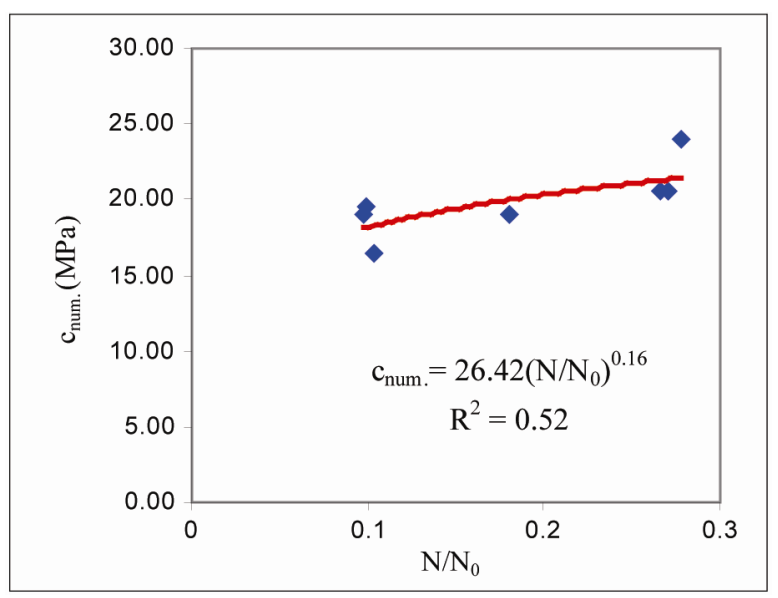

Fig. 2. Influence of $N / N_{0}$ on the concrete cohesion of D-P yield criterion

The influence of $N / N_{0}$ on the concrete cohesion has been investigated using the columns tested by Atalay and Penzien (1975). The results of NLFEA for $N / N_{0}=0.098 \sim$ 0.278 indicate that the concrete cohesion increases slightly with $N / N_{0}$, as shown in Fig. 2. It has been assumed that the concrete cohesion is proportional to $\left(N / N_{0}\right)^{0.16}$ for the columns considered in this study. The variation of concrete cohesion for $\mathrm{RC}$ columns can be expressed as follows:

$$
c_{\text {num }}=26.42\left(\frac{N}{N_{0}}\right)^{0.16} .
$$

\subsubsection{Influence of compressive strength of concrete on concrete cohesion}

A regression analysis has been undertaken to identify the influence of $f_{c}$ on the concrete cohesion using the results of NLFEA. The effect of $f_{c}$ on the concrete cohesion is illustrated in Fig. 3, which shows that the proposed equation matches closely with the numerical results. The results of NLFEA for $a / d=2.50 \sim 5.50, N / N_{0}=0.07 \sim 0.63$, 
$f_{c}=27.40 \mathrm{MPa} \sim 115.80 \mathrm{MPa}, \rho=1.67 \% \sim 3.81 \%$ and $\rho_{w} f_{y w}=0.55 \sim 12.76 \mathrm{MPa}$ indicate that the concrete cohesion increases as $f_{c}$ increases for all columns. It has been assumed that the concrete cohesion is proportional to $f_{c}^{0.48}$ for all considered ranges of $a / d, N / N_{0}$ and $f_{c}$ in this study. The variation of concrete cohesion for RC columns can be expressed as follows:

$$
\frac{c_{\text {num }}}{\left(\frac{a}{d}\right)^{1.37}\left(\frac{N}{N_{0}}\right)^{0.16}}=0.46 f_{c}^{0.48}
$$

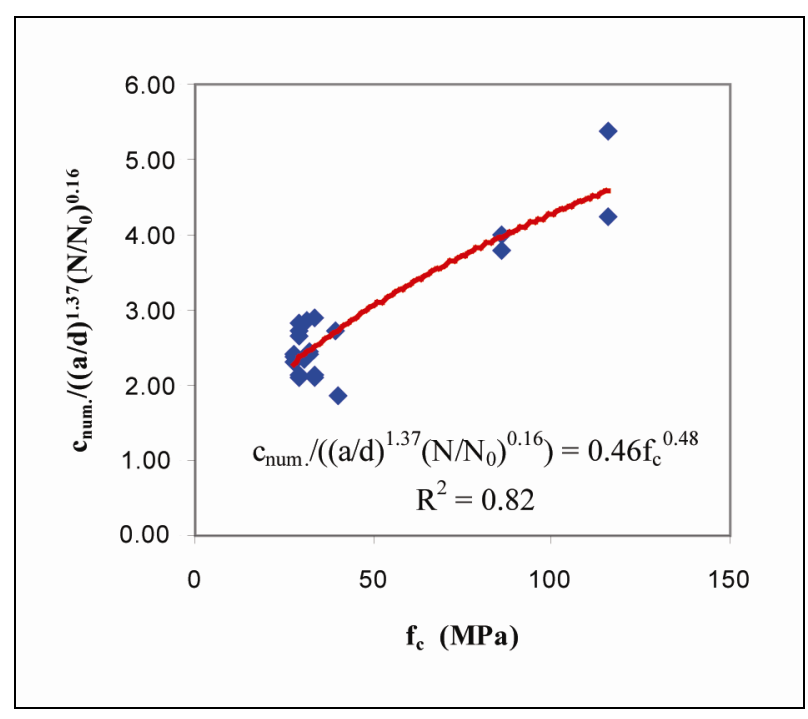

Fig. 3. Influence of $f_{c}$ on the concrete cohesion of D-P yield criterion

\subsection{Proposed concrete cohesion equation for $\mathrm{RC}$ columns}

Based on the previous parametric study, considering the influence of parameters; the span-to-depth ratio $(a / d)$, axial load ratio $\left(N / N_{0}\right)$ and the compressive strength of concrete $\left(f_{c}\right)$, the concrete cohesion of D-P yield criterion for $\mathrm{RC}$ columns can be expressed as:

$$
c_{\text {prop. }}=0.46\left(\frac{a}{d}\right)^{1.37}\left(\frac{N}{N_{0}}\right)^{0.16} f_{c}^{0.48},
$$

in which $f_{c}$ in MPa. The proposed concrete cohesion Eq. (14) captures the effect of $a / d, N / N_{0}$ and $f_{c}$ on the NLFEA results. Table 2 shows the comparison between the concrete cohesion predicted by Eqs (3), (5), (6), (8), the proposed Eq. (14) and the concrete cohesion values of NLFEA results.

\subsection{Evaluation of proposed equation}

The proposed Eq. (14) considers the main parameters for columns $(a / d \geq 2.5)$. The proposed method calculates the value of concrete cohesion in Eq. (14) as a function of span-to-depth ratio $(a / d)$, axial load ratio $\left(N / N_{0}\right)$, and compressive strength of concrete $\left(f_{c}\right)$. Hence, this equation may be considered as one of the more reliable empir- ical equations by taking into account the effects of a/d and $N / N_{0}$ on concrete cohesion. The NLFEA results of columns are discussed as follows.

Fig. 4 compares the concrete cohesion obtained from the proposed Eq. (14) with the values obtained by NLFEA. It can be observed that the values obtained from the proposed Eq. (14) are in good agreement with NLFEA results. The mean value and standard deviation for the ratio of the concrete cohesion obtained from NLFEA to the one predicted by Eq. (14) are 1.02 and 0.12 for all columns, respectively.

Twenty-eight small and large-scale columns tested by four different researchers (Atalay, Penzien 1975; Lu et al. 1999; Muguruma et al. 1989; Azizinamini et al. 1988) have been modelled using the approach described previously (Table 3). Atalay and Penzien (1975) tested a group of square concrete columns. Figs 5 and 6 illustrate that the predicted responses match experimental results in all cases. The ratio of the predicted to the experimental load carrying capacity varies between 1.00 and 1.28 , with an average of 1.15 and a standard deviation of $9 \%$. Therefore, NLFEA point out that there is no effect of stirrup nominal strength $\left(\rho_{w} f_{y w}\right)$ on the accuracy of estimations of the proposed Eq. (14).

Eight square columns tested by Lu et al. (1999) have been modeled. As shown in Figs 5-6, the proposed Eq. (14) predicts concrete cohesion satisfactorily. The ratio of the predicted to experimental load carrying capacity has an average of 0.98 , and the standard deviation is $7 \%$. For columns tested by Muguruma et al. (1989), the ratio of the predicted to the experimental load carrying capacity has an average of 0.98 , and the standard deviation is $10 \%$. It is shown that the predicted load carrying capacities are in very good agreement with the experimental results.

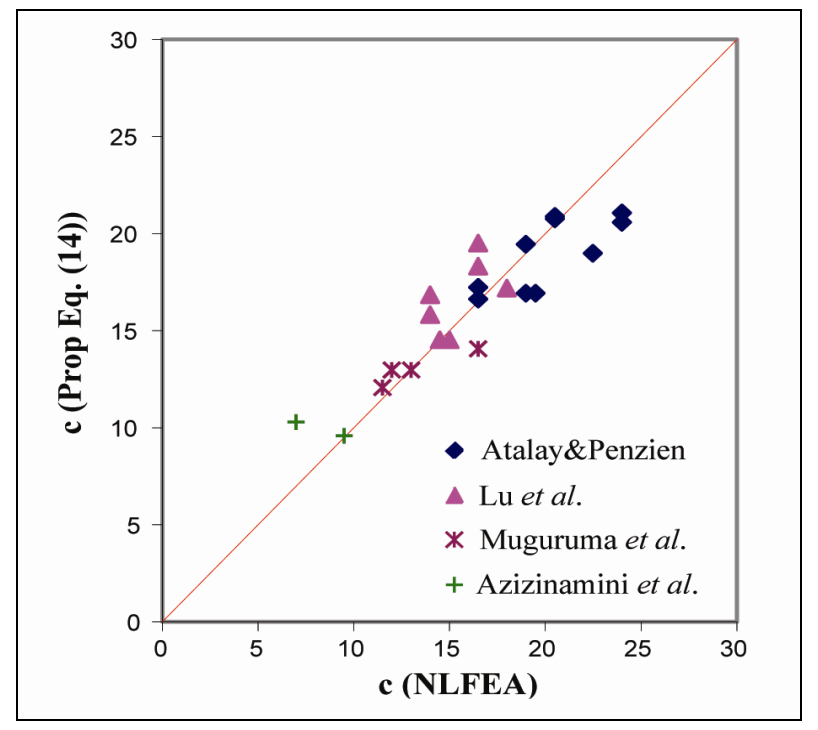

Fig. 4. Proposed Eq. (14) versus NLFEA results of concrete cohesion values 
Table 3. Experimental and predicted load carrying capacities of RC columns

\begin{tabular}{|c|c|c|c|c|c|c|c|c|c|c|c|}
\hline \multirow{3}{*}{ Name } & \multirow{3}{*}{$\begin{array}{c}\begin{array}{c}\text { Exp. Load } \\
(\mathrm{kN})\end{array} \\
(1)\end{array}$} & \multicolumn{5}{|c|}{ Pred. Load (kN) } & \multirow{2}{*}{\multicolumn{5}{|c|}{ Pred. Load / Exp. Load }} \\
\hline & & \multirow{2}{*}{$\begin{array}{c}\text { Eq. (3) } \\
(2)\end{array}$} & \multirow{2}{*}{$\begin{array}{c}\text { Eq. (5) } \\
(3)\end{array}$} & \multirow{2}{*}{$\begin{array}{c}\text { Eq. (6) } \\
(4)\end{array}$} & \multirow{2}{*}{$\begin{array}{c}\text { Eq. (8) } \\
(5)\end{array}$} & \multirow{2}{*}{$\begin{array}{c}\text { Eq. (14) } \\
(6)\end{array}$} & & & & & \\
\hline & & & & & & & $(2) /(1)$ & $(3) /(1)$ & $(4) /(1)$ & $(5) /(1)$ & $(6) /(1)$ \\
\hline $1 S 1^{\mathrm{a}}$ & 62 & 45.1 & 57.0 & 64.4 & 53.9 & 65.1 & 0.73 & 0.92 & 1.04 & 0.87 & 1.05 \\
\hline $2 \mathrm{~S}^{\mathrm{a}}$ & 61 & 42.3 & 58.4 & 67.1 & 42.3 & 68.2 & 0.69 & 0.96 & 1.10 & 0.69 & 1.12 \\
\hline $3 \mathrm{~S}^{\mathrm{a}}$ & 58 & 44.0 & 57.1 & 63.4 & 56.8 & 65.2 & 0.76 & 0.98 & 1.09 & 0.98 & 1.12 \\
\hline $4 \mathrm{~S}^{\mathrm{a}}$ & 71 & 66.4 & 36.8 & 73.6 & 65.6 & 76.0 & 0.94 & 0.52 & 1.04 & 0.92 & 1.07 \\
\hline $5 \mathrm{~S}^{\mathrm{a}}$ & 77 & 40.9 & 44.3 & 75.3 & 62.7 & 77.0 & 0.53 & 0.58 & 0.98 & 0.81 & 1.00 \\
\hline $6 \mathrm{~S}^{\mathrm{a}}$ & 75 & 55.3 & 73.7 & 90.3 & 77.4 & 91.2 & 0.74 & 0.98 & 1.20 & 1.03 & 1.22 \\
\hline $9^{\mathrm{a}}$ & 79 & - & 64.1 & 92.6 & 75.3 & 94.7 & - & 0.81 & 1.17 & 0.95 & 1.20 \\
\hline $10^{\mathrm{a}}$ & 78 & - & 61.3 & 98.5 & 1.8 & 100.2 & - & 0.79 & 1.26 & 0.02 & 1.28 \\
\hline $11^{\mathrm{a}}$ & 82 & - & 62.3 & 90.8 & 70.3 & 94.1 & - & 0.76 & 1.11 & 0.86 & 1.15 \\
\hline $12^{\mathrm{a}}$ & 78.5 & 28.6 & 75.5 & 97.9 & 79.6 & 98.9 & 0.36 & 0.96 & 1.25 & 1.01 & 1.26 \\
\hline $\mathrm{C} 2 \mathrm{H} 1^{\mathrm{b}}$ & 229 & 95.7 & 171.3 & 207.3 & 166.5 & 208.5 & 0.42 & 0.75 & 0.91 & 0.73 & 0.91 \\
\hline $\mathrm{C} 3 \mathrm{H} 2^{\mathrm{b}}$ & 143 & 52.3 & 118.0 & 140.3 & 115.1 & 147.6 & 0.37 & 0.83 & 0.98 & 0.80 & 1.03 \\
\hline $\mathrm{C} 2 \mathrm{~L}^{\mathrm{b}}{ }^{\mathrm{b}}$ & 205 & 95.0 & 169.7 & 205.7 & 169.0 & 206.6 & 0.46 & 0.83 & 1.00 & 0.82 & 1.01 \\
\hline C3L2 ${ }^{b}$ & 138 & 58.0 & 89.1 & 129.6 & 85.0 & 140.6 & 0.42 & 0.65 & 0.94 & 0.62 & 1.02 \\
\hline $\mathrm{C} 5 \mathrm{H} 1^{b}$ & 36 & 5.0 & 25.1 & 31.7 & 26.1 & 32.9 & 0.14 & 0.70 & 0.88 & 0.73 & 0.91 \\
\hline $\mathrm{C}^{2} \mathrm{L1}^{\mathrm{b}}$ & 33 & 4.3 & 23.3 & 29.3 & 20.9 & 31.0 & 0.13 & 0.71 & 0.89 & 0.63 & 0.94 \\
\hline $\mathrm{C} 5 \mathrm{H} 2^{\mathrm{b}}$ & 45 & - & 30.3 & 37.8 & 30.0 & 40.9 & - & 0.67 & 0.84 & 0.67 & 0.91 \\
\hline $\mathrm{C} 5 \mathrm{~L} 2^{\mathrm{b}}$ & 34 & - & 27.9 & 36.5 & 28.6 & 37.6 & - & 0.82 & 1.07 & 0.84 & 1.11 \\
\hline $\mathrm{AL}-1^{\mathrm{c}}$ & 243 & - & - & 337.7 & 240.8 & 256.7 & - & - & 1.39 & 0.99 & 1.06 \\
\hline $\mathrm{AH}-1^{\mathrm{c}}$ & 244 & - & - & 338.0 & 240.8 & 257.8 & - & - & 1.39 & 0.99 & 1.06 \\
\hline $\mathrm{AL}-2^{\mathrm{c}}$ & 242 & - & - & 434.4 & - & 238.0 & - & - & 1.80 & - & 0.98 \\
\hline $\mathrm{AH}-2^{\mathrm{c}}$ & 247 & - & - & 438.0 & - & 265.3 & - & - & 1.77 & - & 1.07 \\
\hline $\mathrm{BL}-1^{\mathrm{c}}$ & 255 & - & 332.4 & 189.4 & - & 252.0 & - & 1.30 & 0.74 & - & 0.99 \\
\hline $\mathrm{BH}-1^{\mathrm{c}}$ & 255 & - & - & 346.0 & 189.4 & 252.0 & - & - & 1.36 & 0.74 & 0.99 \\
\hline$B L-2^{c}$ & 289 & - & - & 427.8 & 301.7 & 241.2 & - & - & 1.48 & 1.04 & 0.83 \\
\hline $\mathrm{BH}-2^{\mathrm{c}}$ & 288 & - & - & 263.2 & 301.7 & 241.2 & - & - & 0.91 & 1.05 & 0.84 \\
\hline $\mathrm{NC}-2^{\mathrm{d}}$ & 467 & 319.2 & 345.6 & 537.0 & 448.2 & 489.0 & 0.68 & 0.74 & 1.15 & 0.96 & 1.05 \\
\hline $\mathrm{NC}-4^{\mathrm{d}}$ & 490 & - & - & 652.5 & 477.0 & 565.8 & - & - & 1.14 & 0.97 & 1.15 \\
\hline
\end{tabular}
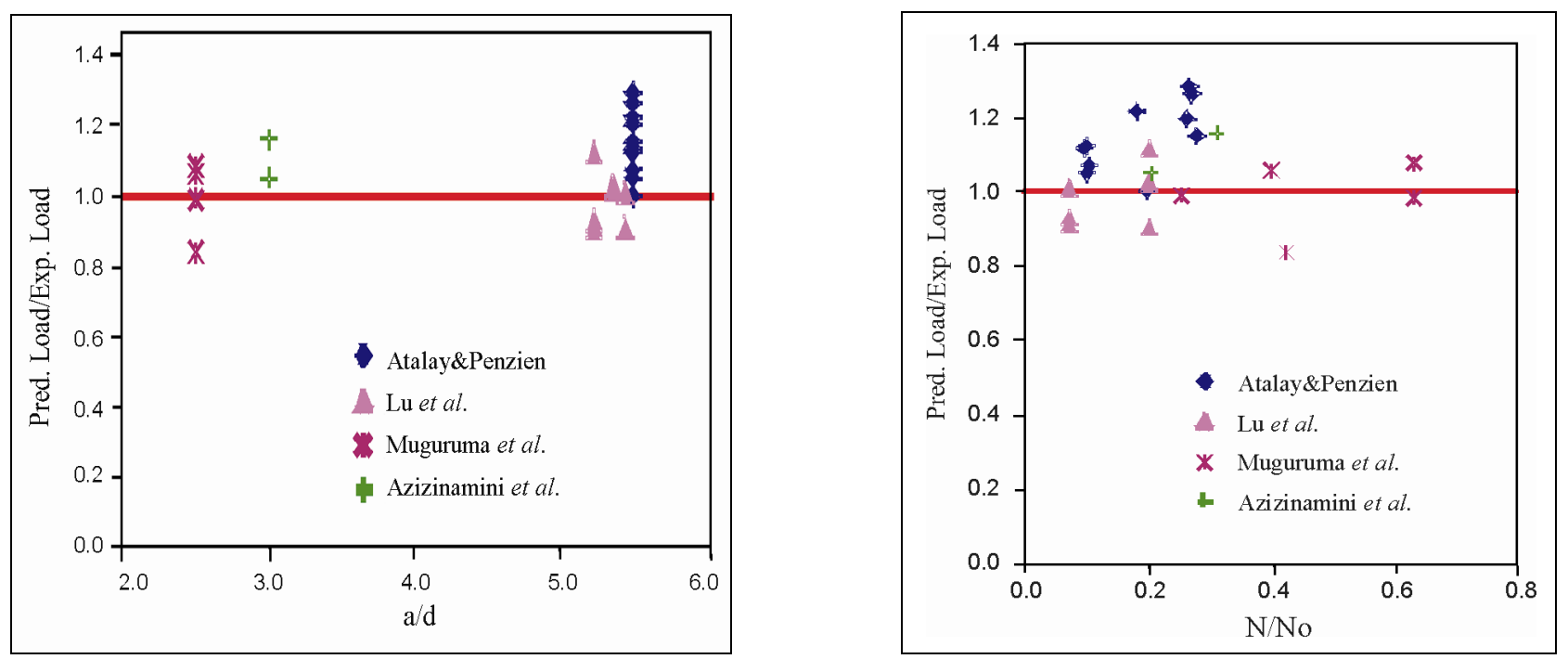

Fig. 5. Comparing prediction load based on proposed Eq. (14) with experimental load for various $a / d$ and $N / N_{0}$ ratios 

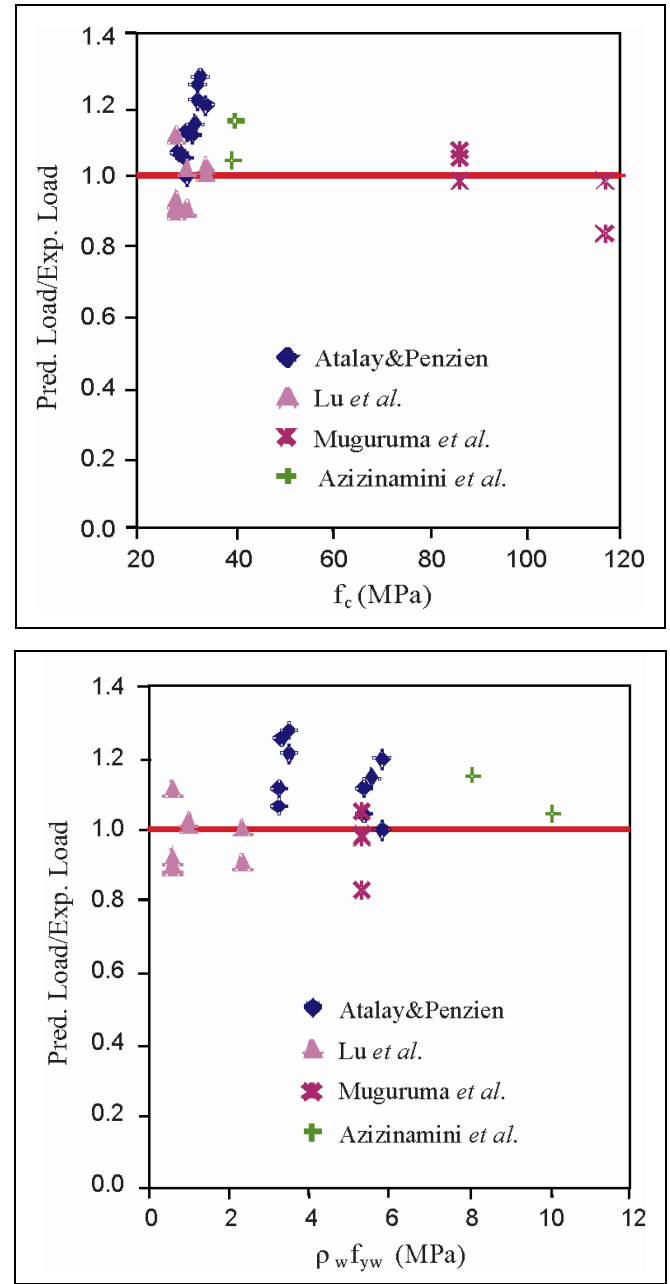

Fig. 6. Comparing prediction load based on proposed Eq. (14) with experimental load for various $f_{c}$ and $\rho_{w} f_{y w}$

\section{Conclusions}

This paper has been concerned with a simple elastoplastic approach for NLFEA of RC columns. The following conclusions can be drawn based on the results of the analyses:

- Twenty-eight small and large-scale column specimens tested by four different researchers (Atalay, Penzien 1975; Lu et al. 1999; Muguruma et al. 1989; Azizinamini et al. 1988) have been numerically modelled using the proposed approach. Comparisons between analytical and experimental results confirm that the proposed numerical approach is appropriate for estimating the load-carrying capacities of RC columns;

- The ratio of the predicted to experimental load carrying capacities is between 0.83 and 1.28 . It is shown that a good correlation exists between the experimental results and the predictions by the proposed Eq. (14);

- The proposed equation shows several capabilities for dealing with nonlinear behaviour of RC columns. But, further calibrations using the experimental results reported in the literature are needed to obtain a better performance.

\section{References}

ACI Committee 318. 2008. Building code requirements for structural concrete (ACI 318M-08) and commentary, American Concrete Institute, Farmmington Hills, MI. $473 \mathrm{p}$.

ACI Committee 363R-92. 1997. State-of-the-art report on highstrength concrete. Reported by ACI Committee 363, Farmington Hills, MI. 55 p.

ANSYS 11.0, 2010. Theory Reference Manual. SAS IP, Inc.

Arslan, G. 2007. Sensitivity study of the Drucker-Prager modeling parameters in the prediction of the nonlinear response of reinforced concrete structures, Materials \& Design 28(10): 2596-2603.

http://dx.doi.org/10.1016/j.matdes.2006.10.021

Atalay, M. B.; Penzien, J. 1975. The seismic behavior of critical regions of reinforced concrete components as influenced by moment, shear and axial force. Report No. EERC 7519, University of California, Berkeley. $226 \mathrm{p}$.

Azizinamini, A.; Johal, L. S.; Hanson, N. W.; Musser, D. W.; Corley, W. G. 1988. Effects of transverse reinforcement on seismic performance of columns - A partial parametric investigation. Project No. CR-96 17, Construction Technology Laboratories, Skokie, Illinois.

Bae, S.; Bayrak, O. 2009. Drift capacity of reinforced concrete columns, ACI Structural Journal 106(4): 405-415.

Chen, B.; Mau, S. T. 1989. Recalibration of a plastic-fracturing model for concrete confinement, Cement and Concrete Research 19(1): 143-154. http://dx.doi.org/10.1016/0008-8846(89)90074-4

Chen, W.-F. 1982. Plasticity in reinforced concrete. New York: McGraw-Hill Company. 816 p.

Deniaud, D.; Neale, K. W. 2006. An assessment of constitutive models for concrete columns confined with fibre composite sheets, Composite Structures 73(3): 318-330. http://dx.doi.org/10.1016/j.compstruct.2005.02.003

Design guidance for high strength concrete. 1998. Concrete Society Technical (CST) Report 49, UK. 168 p.

Eid, R.; Paultre, P. 2007. Plasticity-based model for circular concrete columns confined with fibre-composite sheets, Engineering Structures 29(12): 3301-3311. http://dx.doi.org/10.1016/j.engstruct.2007.09.005

Eid, R.; Dancygier, A. N.; Paultre, P. 2007. Elastoplastic confinement model for circular concrete columns, Journal of Structural Engineering ASCE 133(12): 1821-1831. http://dx.doi.org/10.1061/(ASCE)0733-9445(2007)133: 12(1821)

Eurocode 2: Design of Concrete Structures. Part 1-1: General Rules and Rules for Buildings. Brussels, 2004. 225 p.

Karabinis, A. I.; Kiousis, P. D. 1994. Effects of confinement on concrete columns: plasticity approach, Journal of Structural Engineering ASCE 120(9): 2747-2767. http://dx.doi.org/10.1061/(ASCE)0733-9445(1994)120: 9(2747)

Karabinis, A. I.; Kiousis, P. D. 1996. Strength and ductility of rectangular concrete columns: a plasticity approach, Journal of Structural Engineering ASCE 122(3): 267274. http://dx.doi.org/10.1061/(ASCE)0733-9445(1996) 122: $3(267)$

Karabinis, A. I.; Rousakis, T. C. 2002. Concrete confined by FRP material: a plasticity approach, Engineering Structures 24(7): 923-932. http://dx.doi.org/10.1016/S01410296(02)00011-1 
Karakoç, C.; Köksal, H. O. 1997. The modelling of concrete fracture. Research Study, Politecnico di Milano, Italy. Vol. 18: 271-283.

Köksal, H. O.; Arslan, G. 2004. Damage analysis of RC beams without web reinforcement, Magazine of Concrete Research 56(4): 231-241. http://dx.doi.org/10.1680/macr.2004.56.4.231

Köksal, H. O. 1998. Modeling of concrete fracture. $\mathrm{PhD}$ thesis. Bogazici University, İstanbul.

Lan, Y. M. 1998. Finite element study of concrete columns with fiber composite jackets. PhD thesis. School of Civil Engineering, Purdue University, USA.

Lu, Y.; Vintzileou, E.; Zhang, G.-F.; Tassios, T. P. 1999. Reinforced concrete scaled columns under cyclic actions, Soil Dynamics and Earthquake Engineering 18(2): 151-167. http://dx.doi.org/10.1016/S0267-7261(98)00037-2

Lubliner, J.; Oliver, J.; Ollers, S.; Oñate, E. 1989. A plasticdamage model for concrete, International Journal of Solids and Structures 25(3): 299-326. http://dx.doi.org/10.1016/0020-7683(89)90050-4

Lynn, A. C. 2001. Seismic evaluation of existing reinforced concrete building columns. PhD thesis. Department of Civil and Environmental Engineering, University of California, Berkeley, USA.

Mahfouz, I.; Rizk, T.; Sarkani, S. 2001. An innovative FRP confining system for repairing rectangular columns, in Construction and materials issues, Proceedings of the second congress, 2001, ASCE and Construction Institute, 6-25.

Majewski, T.; Bobinski, J.; Tejchman, J. 2008. FE analysis of failure behaviour of reinforced concrete columns under eccentric compression, Engineering Structures 30(2): 300-317.

http://dx.doi.org/10.1016/j.engstruct.2007.03.024

Mirmiran, A.; Zagers, K.; Yuan, W. 2000. Nonlinear finite element modeling of concrete confined by fiber composites, Finite Elements in Analysis and Design 35(1): 79-96. http://dx.doi.org/10.1016/S0168-874X(99)00056-6

Muguruma, H.; Watanabe, F.; Komuro, T. 1989. Applicability of high strength concrete to reinforced concrete ductile column, Transactions of the Japan Concrete Institute 11: 309-316.

Oh, B. 2002. A plasticity model for confined concrete under uniaxial loading. PhD thesis. Lehigh University, USA.

Oller, S.; Oñate, E.; Oliver, J.; Lubliner, J. 1990. Finite element nonlinear analysis of concrete structures using a "plasticdamage model", Engineering Fracture Mechanics 35(1-3): 219-231.

http://dx.doi.org/10.1016/0013-7944(90)90200-Z
Panagiotakos, T. B.; Fardis, M. N. 2001. Deformations of reinforced concrete members at yielding and ultimate, $A C I$ Structural Journal 98(2): 135-148.

Pankaj, P.; Lin, E. 2005. Material modelling in the seismic response analysis for the design of RC framed structures, Engineering Structures 27(7): 1014-1023. http://dx.doi.org/10.1016/j.engstruct.2005.02.003

Phillips, D. V.; Bisheng, Z. 1993. Direct tension tests on notched and un-notched plain concrete specimens, Magazine of Concrete Research 45(162): 25-35. http://dx.doi.org/10.1680/macr.1993.45.162.25

Pujol, S.; Sözen, M. A.; Ramírez, J. A. 2000. Transverse reinforcement for columns of RC frames to resist earthquakes, Journal of Structural Engineering ASCE 126(4): 461466. http://dx.doi.org/10.1061/(ASCE)0733-9445(2000) $126: 4(461)$

Richart, F. E.; Brandtzaeg, A.; Brown, R. L. 1929. The failure of plain and spirally reinforced concrete in compression. University of Illinois Engineering Experimental Station, Bulletin No. 190 26(31): 3-72.

Rochette, P.; Labossie're, P. 1996. A plasticity approach for concrete columns confined with composite materials, in Proc. of Advanced Composite Materials in Bridges and Structures (CSCE), 1996, 359-366.

Rousakis, T. C.; Karabinis, A. I.; Kiousis, P. D. 2007. FRPconfined concrete members: axial compression experiments and plasticity modelling, Engineering Structures 29(7): 1343-1353.

http://dx.doi.org/10.1016/j.engstruct.2006.08.006

Sasani, M. 2007. Life-safety and near-collapse capacity models for seismic shear behavior of reinforced concrete columns, ACI Structural Journal 104(1): 30-38.

Sezen, H. 2002. Seismic response and modeling of reinforced concrete building columns. $\mathrm{PhD}$ thesis. Department of Civil and Environmental Engineering, University of California, Berkeley, USA.

Shahawy, M.; Mirmiran, A.; Beitelman, T. 2000. Tests and modeling of carbon-wrapped concrete columns, Composites Part B: Engineering 31(6-7): 471-480. http://dx.doi.org/10.1016/S1359-8368(00)00021-4

Yu, T.; Teng, J. G.; Wong, Y. L.; Dong, S. L. 2010a. Finite element modeling of confined concrete-I: Drucker-Prager type plasticity model, Engineering Structures 32(3): 665679. http://dx.doi.org/10.1016/j.engstruct.2009.11.014

Yu, T.; Teng, J. G.; Wong, Y. L.; Dong, S. L. 2010b. Finite element modeling of confined concrete-II: Plastic-damage model, Engineering Structures 32(3): 680-691. http://dx.doi.org/10.1016/j.engstruct.2009.11.013

Guray ARSLAN. Associate Professor at the Department of Civil Engineering, Y1ldiz Technical University. He received his PhD from the University of Yıldız Technical, Istanbul, Turkey. His main research interest is the behavior of reinforced concrete members under monotonic and cyclic actions.

Melih HACISALIHOGLU. Civil Engineer. He received his Ms Degree from the Y1ldiz Technical University, Istanbul, Turkey. His main research interest is the behavior of reinforced concrete beams and columns under loading. 